\title{
Sosialisasi Konstruksi Bangunan Sederhana Tahan Gempa
}

\author{
Hilfi Harisan Ahmad*, Dani Widiyansah \\ Universitas Muhammadiyah Jember \\ Email: hilfiharisana@unmuhjember.ac.id, daniwidiansyah@unmuhjember.ac.id
}

Diterima: Mei 2021 | Dipublikasikan: Juni 2021

\begin{abstract}
ABSTRAK
Letak Indonesia berada pada tempat yang rawan gempa yaitu Wilayah Indonesia terletak pada tiga lempeng tektonik di dunia yaitu: lempeng Australia di selatan, lempeng EuroAsia di barat dan lempeng Samudra Pasifik di timur yang dapat menunjang terjadinya sejumlah bencana. Terjadinya gempa dapat menimbulkan kerugian,seperti kerugian material dan korban jiwa. Untuk mengurangi terjadinya korban jiwa dapat dilakukan dengan membuat bangunan yang tahan terhadap gempa. Pengabdian masyarakat mengambil tema sosialisasi rumah sederhana dikarenakan banyak penduduk di daerah tersebut masih menggunakan rumah sederhana satu lantai. Agar pembahasan tidak melebar penulis memberi batasan masalah dalam sosialisasi ini hanya membahas bangunan sederhana satu lantai saja. Diharapkan dengan adanya sosialisasi tentang rumah sederhana tahan gempa ini masyarakat menjadi lebih paham akan pentingnya rumah yang sesuai dengan standar yang ditetapkan,sehingga tidak menjadikan gempa sesuatu yang menakutkan bila sudah dilakukan antisipasi sejak awal.
\end{abstract}

Kata kunci: Indonesia, bangunan,gempa

\begin{abstract}
Indonesia's location is in an earthquake-prone area, namely the Indonesian region which lies on three tectonic plates in the world, namely: the Australian plate in the south, the Euro-Asia plate in the west and the Pacific Ocean plate in the east which can support a number of disasters. The occurrence of an earthquake can cause losses, such as material loss and casualties. To reduce the occurrence of casualties, it can be done by making buildings that are resistant to earthquakes. Community service takes the theme of simple house socialization because many residents in the area still use simple one-story houses. In order for the discussion not to widen, the writer gives a limitation to the problem in this socialization that only discusses a simple onestory building. It is hoped that with the socialization of simple earthquake-resistant houses, the community will understand more about the importance of houses that comply with the set standards, so that they do not make earthquakes something scary if they have been anticipating it from the start.
\end{abstract}

Keywords: Indonesia, building, earthquake

\section{PENDAHULUAN}

Letak Indonesia berada pada tempat yang rawan gempa yaitu Wilayah Indonesia terletak pada tiga lempeng tektonik di dunia yaitu: lempeng Australia di selatan, lempeng Euro-Asia di barat dan lempeng Samudra Pasifik di timur yang dapat menunjang terjadinya sejumlah bencana. Terjadinya gempa dapat menimbulkan kerugian,seperti kerugian material dan korban jiwa.Bila terjadi gempa maka bangunan gedung atau struktur lainnya yang direncanakan untuk harus tetap beroperasi (SNI 1726-2019), Untuk mengurangi terjadinya korban jiwa dapat dilakukan dengan membuat bangunan yang tahan terhadap gempa. Membuat bangunan tahan gempa telah diberikan standar oleh Pemerintah Indonesia melalui Standar Nasional Indonesia (SNI), permasalahan dilapangan tidak semua orang menggunakan SNI dalam membuat bangunan. Banyak hal yang menyebabkan tidak digunakannya SNI seperti ketidaktahuan,keterbatasan akses dalam memperoleh informasi. Tidak digunakannya SNI dalam membuat bangunan akan memperbesar resiko menjadi korban bila terjadi gempa. Prinsip dasar keamanan dalam rumah 
tinggal adalah bila terkena gempa bumi ringan bangunan terebut tidak mengalami kerusakan sama sekali, kemudian bila terkena gempa bumi sedang, bangunan tersebut boleh mengalami kerusakan pada elemen non structural tetapi tidak boleh rusak pada elemen struktur, dan yang terakhir adalah bila bangunan terkena gempa bumi kuat maka bangunan tersebut boleh runtuh namun dapat diperbaiki kembali sehingga dapat difungsikan (Direktorat Jenderal Cipta Karya,2006). Berdasarkan permasalahan tersebut maka penulis melakukan sosialisasi mengenai membuat rumah sederhana yang tahan gempa di daerah Rowo Indah, Kranjingan, Jember. Rumah sederhana adalah rumah yang denahnya simetris dan tidak ada tonjolan, jika terdapat tonjolan,maka toleransi adalah > 25\% dari ukuran denah terbesar(Edward dan Erwinsyah,2020).

\section{METODE PEIAKSANAAN}

Metode Pelaksanaan : Metode pelaksanaan pengabdian masyarakat melalui program sosialisasi konstruksi bangunan sederhana tahan gempa ini adalah dengan menggunakan langkah-langkah sebagai berikut.

1. bekerja sama dengan penduduk sekitar yang memiliki data-data tukang didaerah yang akan digunakan sebagai tempat sosialisasi.

2. berdasarkan data tersebut penulis memberikan undangan untuk menghadiri sosialisai yang penulis lakukan.

3. Pemaparan materi dilakukan oleh penulis sendiri, materi yang dibahas dalam sosialisasi bangunan tahan gempa terdiri dari pekerjaan pondasi sampai dengan pekerjaan atap.

\section{HASIL KEGIATAN}

Luaran dalam sosialisasi ini adalah pemahaman materi tentang konstruksi sederhana yang tahan terhadap gempa yang diharapkan dapat menjadi pedoman dalam membangun rumah sederhana, materi disadur dari Dinas Pekerjaan Umum dan dinas terkait. Target capaian yang diharapkan dalam pengabdian masyarakat yang penulis lakukan adalah tukang bangunan didaerah kranjingan dapat menerapkan informasi yang didapatkan dari sosialisasi pada pekerjaan bangunan yang dilakukan, sehingga meminimalisir terjadinya bangunan yang tidak sesuai standar yang ditetapkan oleh Pemerintah. Dokumentasi banner kegiatan dapat dilihat pada gambar 1. berikut

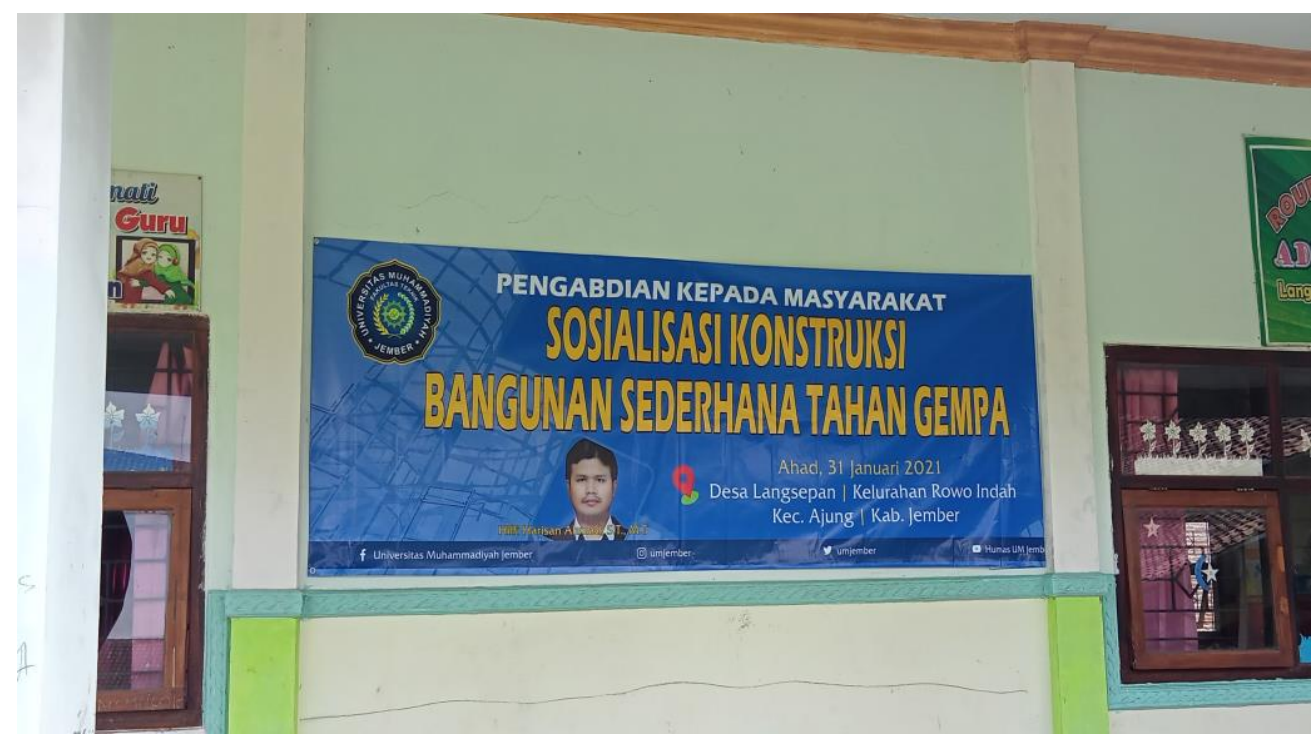

Gambar 1. Banner Kegiatan 
Kegiatan pengabdian masyarakat yang dilakukan pada tanggal 31 Januari Hari Ahad tahun 2021 dan berlokasi di daerah Rowo Indah,Kranjingan, Kabupaten Jember, dilaksanakan dengan mengundang 15 orang yang terdiri dari tukang bangunan terlaksana dengan baik dengan dihadiri oleh 12 orang. Dokumentasi kegiatan sosialisasi konstruksi bangunan sederhana tahan gempa dapat dilihat pada gambar 2 berikut ini.

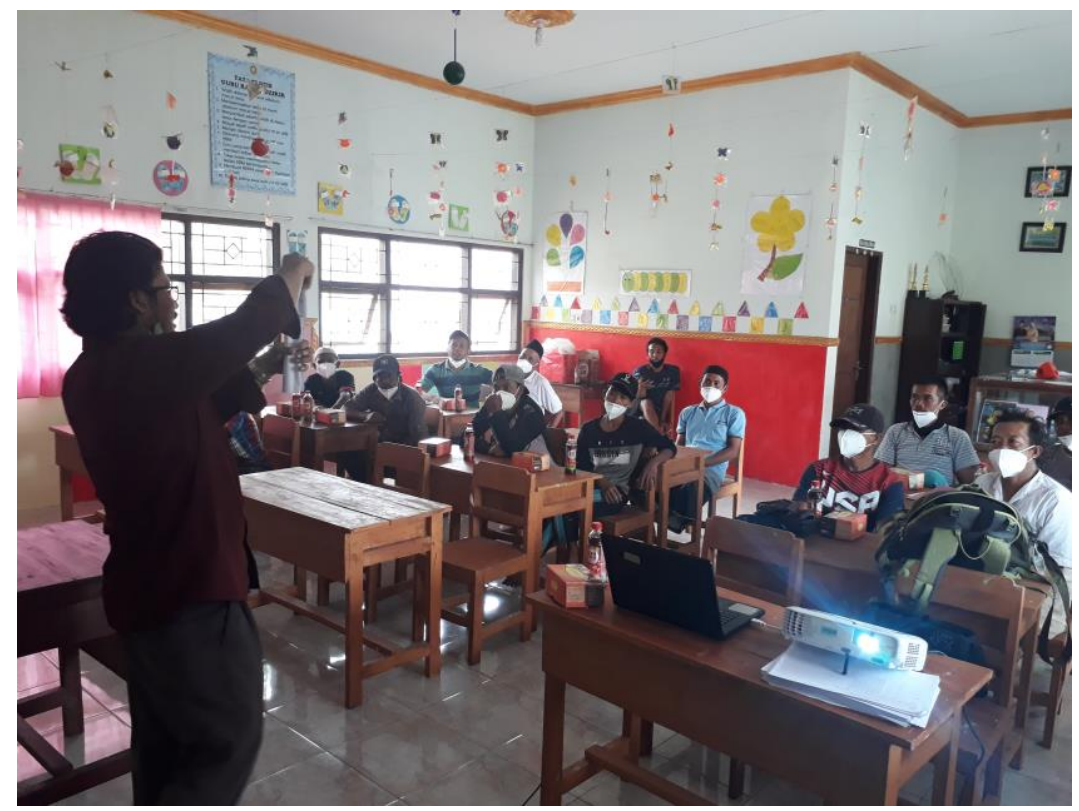

Gambar 2. Proses Kegiatan Sosialisasi dan Diskusi

Acara sosialisasi konstruksi bangunan sederhana tahan gempa ini diselenggarakan dengan mengikuti protokol kesehatan, yaitu peserta sebelum memasuki ruangan wajib mencuci tangan dengan sabun dan memakai masker untuk mengantisipasi penyebaran Covid-19, dapat dilihat pada gambar 3 berikut ini.

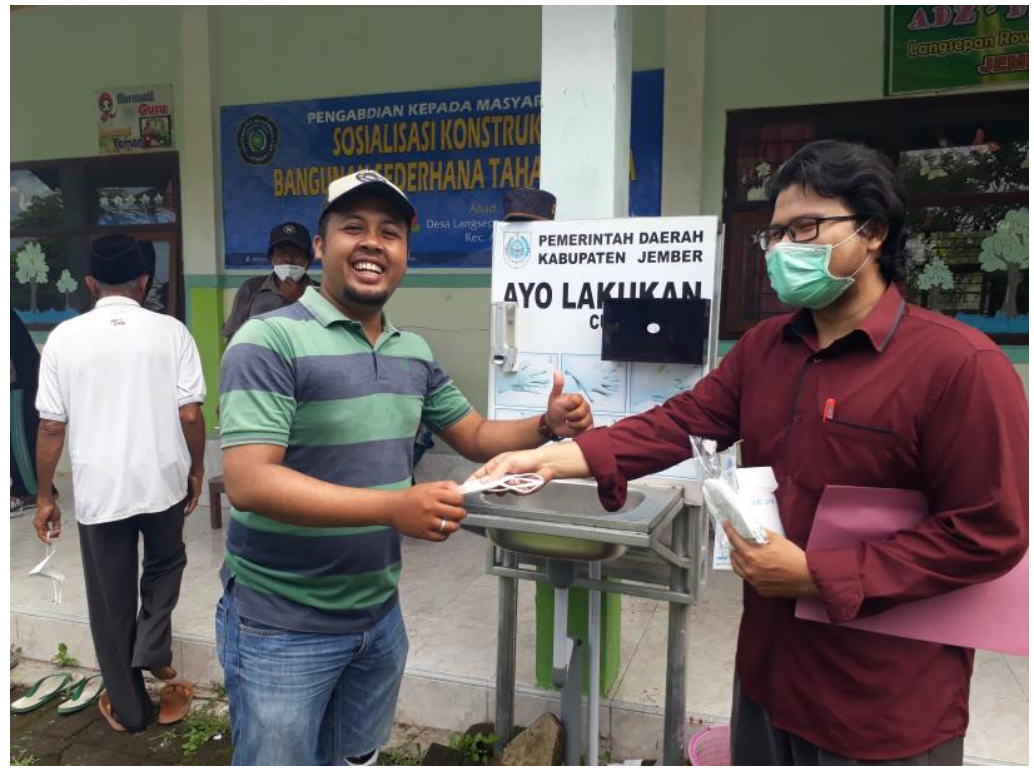

Gambar 3. Proses Penerapan Protokol kesehatan 
Peserta yang notabene adalah tukang bangunan mengikuti acara sosialisasi dengan antusias, diskusi yang dilakukan dalam acara tersebut berjalan dengan baik dan lancar, para peserta saling berdiskusi dan memahami pemaparan materi yang diberikan. Setelah acara berakhir para peserta dan penulis berfoto bersama seperti yang dilihat pada gambar 4 berikut ini.

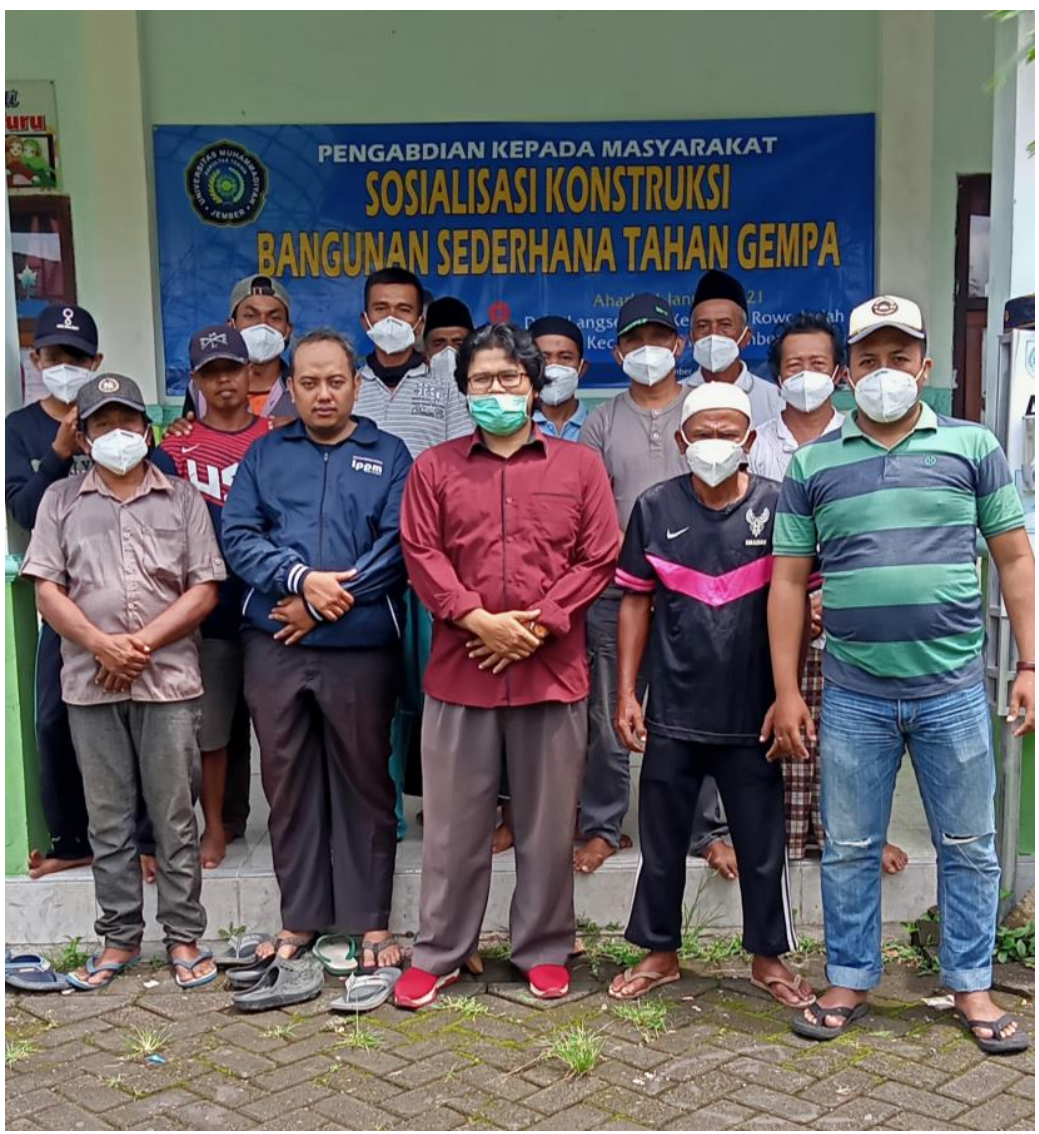

Gambar 4. Prosesi Foto Bersama

\section{KESIMPULAN DAN SARAN}

Kegiatan pengabdian masyarakat dengan tema sosialisasi konstruksi bangunan sederhana tahan gempa yang telah terlaksana ini menghasilkan kesimpulan sebagai berikut,

1. Para peserta dapat memahami pemaparan melalui presentasi yang dilakukan oleh pemateri dengan baik.

2. Diskusi yang dilakukan setelah acara pemaparan presentasi adalah membahas pekerjaan yang selama ini dilakukan dengan membandingkan dengan contoh pekerjaan yang ada dalam presentasi tersebut.

3. Ada beberapa peserta yang telah melakukan pekerjaan mereka sesuai dengan contoh pekerjaan yang ada dalam presentasi tersebut.

4. Ada beberapa peserta yang baru mengetahui pekerjaan mereka masih kurang sesuai dengan contoh pekerjaan yang ada dalam presentasi tersebut.Para peserta dapat memahami efek dari pekerjaan yang tidak sesuai dengan peraturan yang berlaku, contoh, tekukan pada sengkang kolom yang harus 135 derajat akan berdampak positif bagi 
keamanan bangunan dan isinya dibandingkan dengan sengkang pada kolom yang hanya ditekuk seadanya. Penggunaan tulangan dapat menggunakan tulangan polos dan ulir

Secara umum acara pengabdian masyarakat melalui sosialisasi ini diharapkan dapat memberikan efek yang positif kepada peserta yang bekerja sebagai tukang bangunan yang mengikuti, saran untuk kegiatan ini adalah kegiatan sosialisasi semacam ini harus selalu dilakukan secara rutin dengan tema yang sejenis dan dapat diberikan keilmuan terbaru dengan porsi dan materi yang lebih banyak, sehingga ilmu dapat terserap secara keseluruhan, selain itu harus dilaksanakan juga pelatihan yang berkaitan dengan tema tersebut dengan mengundang dinas terkait. Kegiatan sosialiasi ini juga dapat dilakukan dengan bekerjasama bersama pihak apikator untuk diadakan pelatihan produk tertentu seperti aplikator baja ringan, atau juga dapat bekerja sama dengan pabrik bahan bangunan, seperti pabrik semen. Semoga dengan adanya pengabdian masyarakat ini transfer ilmu pengetahuan dari dunia akademik (kampus) kepada masyarakat dapat terserap dengan baik dan dapat diimplementasikan oleh masyarakat dengan baik

\section{UCAPAN TERIMA KASIH :}

Ucapan terima kasih sebesar-besarnya penulis haturkan kepada

1. LPPM Universitas Muhammadiyah Jember

2. Pondok Pesantren RA adz Dzikir,desa Rowo Indah Kecamatan Ajung, Kabupaten Jember

3. Bapak Dani Widiyansah, ST, MT.

Serta semua pihak yang telah membantu terselenggaranya kegiatan pengabdian masyarakat ini

\section{DAFTAR PUSTAKA}

SNI 2847 Persyaratan Beton Struktural untuk Bangunan Gedung, 2019, Badan Standar Nasional Indonesia, Jakarta.

Agus Bambang Siswanto dan M Afif Salim (2018) Kriteria Dasar Perencanaan Struktur Bangunan Tahan Gempa. Jurnal Teknik Sipil UNTAG Semarang. Volume 11-2018

Edward Rizky Ahadian dan Erwinsyah Tuhuteru (2020) Evaluasi Bangunan Sederhana Tahan Gempa. Jurnal SIPILsains. Volume 10 Nomor 1 - Maret 2020

SNI 1726 Tata Cara Perencanaan Tahan Gempa Untuk Struktur Bangunan Gedung Dan Non Gedung, 2019, Badan Standar Nasional Indonesia, Jakarta.

Pedoman Teknis Rumah dan Bangunan Gedung Tahan Gempa dilengkapi dengan Metode dan

Cara Perbaikan kerusakan, Juni 2006, Direktorat Jenderal Cipta Karya, Jakarta. 